\title{
COMPARISON OF PHYSICAL FITNESS IN INFECTED AND NON-INFECTED CHILDREN WITH SOIL-TRANSMITTED HELMINTH
}

\section{Esfayanti Sianturi}

\section{Syahril Pasaribu*}

\section{Ayodhia Pitaloka} Pasaribu
Department Of Child Health, Faculty Of Medicine, Universitas Sumatera Utara, Medan, Indonesia

Department Of Child Health, Faculty Of Medicine, Universitas Sumatera Utara, Medan, Indonesia *Corresponding Author

Department Of Child Health, Faculty Of Medicine, Universitas Sumatera Utara, Medan, Indonesia

\section{ABSTRACT}

Soil-transmitted helminth (STH) infection can cause decreasing physical fitness in children, but the evidence available is limited. The aim to compare physical fitness in infected and non-infected children with STH. A cross-sectional study was done in school children in Talawi districts, Batubara regency, North Sumatera province, Indonesia. The study was conducted from July to September 2018. Physical fitness was assessed consisted of a cardiorespiratory component by measuring the consumption of oxygen uptake $\left(\mathrm{VO}_{2} \mathrm{max}\right)$, and musculoskeletal component by measuring muscular strength and flexibility. Statistical analysis using chi-square and Mann-Whitney test to assess physical fitness between groups. There were 140 school children enrolled in divided equally infected and non-infected children. Muscular strength and flexibility were significantly different between infected and non-infected school children. However, there was no different in $\mathrm{VO}_{2}$ max between groups. Muscular strength and flexibility are weaker in infected school children compare to non-infected children.

\section{KEYWORDS : Soil-transmitted Helminth Infection, Physical Fitness, Muscular Strength, Muscular Flexibility,} Children.

\section{INTRODUCTION}

Soil-transmitted helminth (STH) infections caused by Ascaris lumbricoides, Trichuris trichiura, Strongyloides stercoralis, and hookworm (Ancylostoma duodenale and Necator americanus) are the most common worm infection in humans. ${ }^{[1]}$ More than two billion people worldwide infected with STH in 2012. ${ }^{[2]}$ In 2011, an estimated 875 million children were infected with STH, $70 \%$ of whom were school-age children. The prevalence of helminthiasis in Indonesia ranged from 20 to $86 \%$, with an average of $30 \%$ in 2015 . $^{[3,4]}$

Decreasing physical fitness is a manifestation of the body's inability to maintain adequate oxygen supply to the tissues. This can be caused by various causes, including chronic infection by STH infection. ${ }^{[5]}$ Soil-transmitted helminth infection generally can cause symptoms such as anorexia, abdominal pain, nausea, vomiting, diarrhea, fever, fatigue, and dysentery. This symptom will cause a decrease in appetite, which can result in food and nutritional input disrupted, finally, this condition will result in a decrease in physical fitness in children. ${ }^{[6]}$

A study in China in 2011 was reported that children infected with T. trichiura experienced a decrease in physical fitness by using a 20-meter shuttle run test. ${ }^{[5]}$ A study in Yunan in 2011 reported that decreased physical fitness was happened because of anemia and short stature and associated with chronic infection. ${ }^{[7]}$ The objective of this study was to compare physical fitness in infected and non-infected school children with STH.

\section{METHODS}

This was a cross-sectional study conducted in two primary schools in Talawi district, Batubara regency, North Sumatera province from July to September 2018. Total participants of 140 school children were divided equally into two groups, and participants were selected by consecutive sampling. The inclusion criteria were children aged 9 to 12 years, children who were able to follow the study procedure and live in the same area. Children who suffered injuries to the legs and arms, and children with a history of bronchial asthma, anemia, pulmonary TB, malnutrition, obesity, malignancy, congenital heart disease were excluded.

Bodyweight, body height, nutritional status, body mass index (BMI), and hemoglobin level were measured for each participant. Physical fitness of each sample was expressed as the $\mathrm{VO}_{2}$ max estimate using a 20 -meter shuttle run test. Muscular strength was assessed using a handgrip strength test, and muscular flexibility was assessed using a sit and reach test.

Age, body weight, body height, and hemoglobin level in infected and non-infected school children with STH were analyzed using Mann-Whitney test. Nutritional status, gender, and BMI test in both groups were analyzed using the Chisquare test. The difference in physical fitness in the two groups was analyzed using the Mann-Whitney test. Processing data using SPSS version 22 software with a significance level of $P$ $<0.05$ and confidence interval (IK) $95 \%$.

This study has been approved by the Health Research Ethical Committee of Medical Faculty, Universitas Sumatera Utara. Before the study start, written informed consent was obtained from the parents or legal guardians.

\section{RESULTS}

\section{BASELINE CHARACTERISTIC}

There were 140 school children potentially available for the study received oral informed consent from their parents or guardians to participate in this study. All of them completed the 20-meter shuttle run test, handgrip strength test, sit and reach test, anthropometric and hemoglobin measurements. The group of infected and non-infected school children with STH was in a similar condition (Table 1).

\section{PHYSICAL FITNESS IN INFECTED AND NON-INFECTED SCHOOL CHILDREN WITH SOIL-TRANSMITTED HEL MINTH}

Median $\mathrm{VO}_{2}$ max of infected and non-infected school children were $40.17 \mathrm{ml} \mathrm{kg}^{-1} \mathrm{~min}^{-1}$, and $40.97 \mathrm{ml} \mathrm{kg}^{-1} \mathrm{~min}^{-11}$ respectively. Based on statistical analysis, $\mathrm{VO}_{2} \mathrm{max}$ in the two groups was not significantly different $(P=0.169)$. However, muscular strength and flexibility were significantly different between 
infected and non-infected school children $(\mathrm{P}<0.05)$ (Table 2).

PHYSICALFITNESS BASED ON PARASITOLOGY STATUS

In this study, muscular strength and flexibility were found significantly different in positive and negative school children with $T$. trichiura $(\mathrm{P}<0.05)$. However, only muscular flexibility was found significantly different in positive and negative school children with $A$. lumbricoides $(\mathrm{P}<0.05$ (Table 3$)$.

Table 1. Baseline characteristic

\begin{tabular}{|c|c|c|c|}
\hline \multirow[t]{2}{*}{ Characteristics } & \multicolumn{2}{|c|}{ STH infection } & \multirow[t]{2}{*}{ P Value } \\
\hline & $\begin{array}{l}\text { Infected } \\
(\mathrm{n}=70)\end{array}$ & $\begin{array}{c}\text { Non-infected } \\
(\mathrm{n}=70)\end{array}$ & \\
\hline \multicolumn{4}{|l|}{ Sex, n (\%) } \\
\hline Male & 39 (55.7) & $33(47.1)$ & 0.310 \\
\hline Female & $31(44.3)$ & $37(52.9)$ & \\
\hline Age, year, mean (SD) & $10.0(1.11)$ & $9.8(0.86)$ & 0.346 \\
\hline Weight, kg, mean(SD) & $24.5(4.73)$ & $25.7(5.45)$ & 0.169 \\
\hline Height, $\mathrm{cm}$, mean (SD) & $126.9(7.42)$ & $128.1(7.05)$ & 0.373 \\
\hline \multicolumn{4}{|l|}{ Nutrition status, n (\%) } \\
\hline Underweight & $20(28.6)$ & $11(15.7)$ & 0.150 \\
\hline Normoweight & $47(67.1)$ & $57(81.4)$ & \\
\hline Overweight & $3(4.3)$ & $2(2.9)$ & \\
\hline
\end{tabular}

\begin{tabular}{|l|c|c|c|}
\hline BMI, n (\%) & $19(27.1)$ & $17(24.3)$ & 0.871 \\
$\quad$ Underweight & $50(71.4)$ & $51(72.9)$ & \\
$\quad$ Normal & $1(1.4)$ & $2(2.9)$ & \\
Overweight & $12.1(0.85)$ & $12.5(0.75)$ & 0.011 \\
\hline Hemoglobin, gr/dL, & & & \\
mean (SD) & & \\
\hline
\end{tabular}

Note: $\mathrm{n}=$ total number of subject, SD: Standard deviation

Table 2. Comparison of physical fitness of infected and noninfected school children with STH

\begin{tabular}{|l|c|c|c|c|}
\hline $\begin{array}{l}\text { Physical } \\
\text { fitness } \$\end{array}$ & $\begin{array}{c}\text { Infected } \\
(\mathrm{n}=70) \\
\text { Median } \\
(\text { Minimum- } \\
\text { maximum) }\end{array}$ & $\begin{array}{c}\text { Non-Infected } \\
(\mathrm{n}=70) \\
\text { Median } \\
\text { (Minimum- } \\
\text { maximum) }\end{array}$ & $95 \% \mathrm{CI}$ & $\begin{array}{c}\mathrm{P} \\
\text { Value }\end{array}$ \\
\hline $\mathrm{VO}_{2} \mathrm{max}$ & 40.17 & 40.97 & $0.09-$ & 0.169 \\
& $(35.33-47.27)$ & $(36.40-49.17)$ & 0.20 & \\
\hline Muscular & 9.75 & 12.15 & $0.001-$ & $<0.001$ \\
Strength & $(5.90-11.00)$ & $(8.90-16.00)$ & 0.02 & \\
\hline Muscular & 30.00 & 35.15 & $0.001-$ & $<0.001$ \\
Flexibility & $(20.00-37.00)$ & $(20.50-42.00)$ & 0.02 & \\
\hline
\end{tabular}

Note: CI: Confidence interval

Table 3. Comparison of physical fitness based on the parasitological status

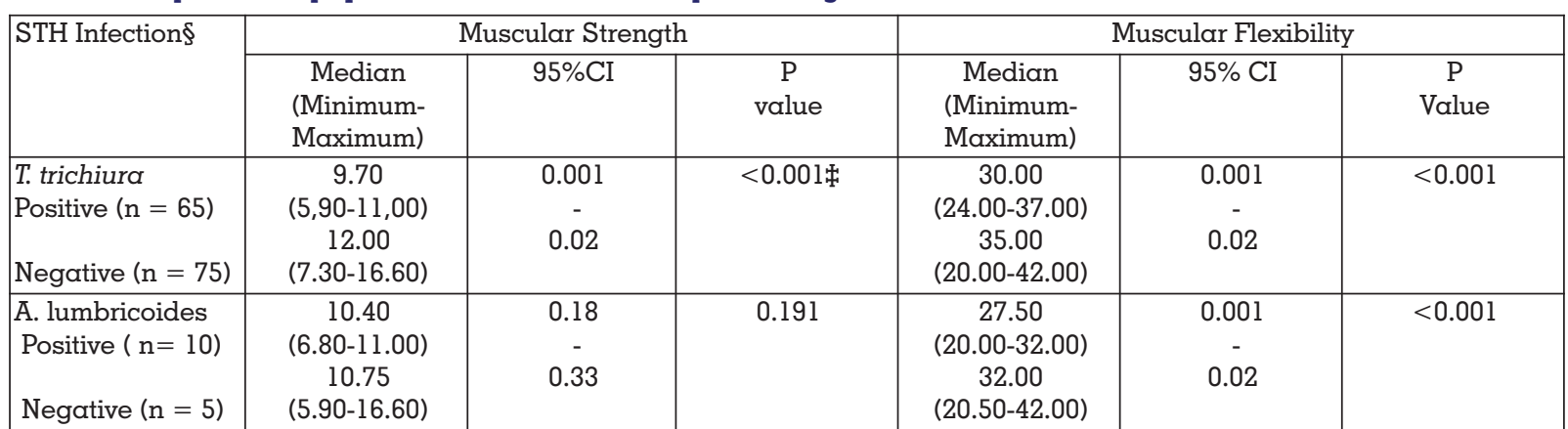

Note: CI: Confidence interval

\section{DISCUSSION}

The prevalence of school children infected with STH in our study was $38.5 \%$ with most of the STH infection found was T. trichiura. Our study, similar to a study at two elementary schools in Belawan, North Sumatera by Jiero (2015), reported that the prevalence of $A$. lumbricoides infection was $37.1 \%{ }^{[8]}$ Our study was different from a study conducted in Karo district in 2004, which reported higher STH infections caused by $A$. lumbricoides $(89.7 \%){ }^{[10]}$ This reason was probably due to school children who participated in this study already had a healthy lifestyle, and each participant had used shoes to go to school and sandals when playing.

In our study, we found that the hemoglobin level was lower in infected children with STH than non-infected school children. The most common type of STH infection in our study is T. trichiura. Our study, similar to a study conducted in Mexico in 2010 in children aged 6 to 10 years reported that T. trichiura infection could be a risk factor for low iron status. ${ }^{[10]}$ A study conducted in China in 2011 reported that there were differences in hemoglobin levels in infected and non-infected school children with T. trichiura. ${ }^{[5]}$ The possibility of low hemoglobin level in infected school children with STH is because T. trichiura infection results in impaired nutrient intake, one of which is iron. This situation can cause anemia. ${ }^{[11]}$

The median value of VO2max in infected school children with $\mathrm{STH}$ is $40.17 \mathrm{ml} / \mathrm{KgBW} /$ minute with a range of VO2max values of 35.33 to $47.27 \mathrm{ml} / \mathrm{kg} \mathrm{BW} /$ minute. While in non- infected school, children with STH had the median value of VO2max was $40.97 \mathrm{ml} / \mathrm{KgBW} /$ minute with a range of 36.40 to 49.17 $\mathrm{ml} / \mathrm{kg} \mathrm{BW} /$ minute. When viewed from the median value of VO2max in our study, the value of VO2max generated is reaching the average to good value. ${ }^{[12]}$ So in our study, the cardiorespiratory function in infected and non-infected school children with STH was good. This result was probably due to in our study we did not found hookworm infection.

The strength of the hand muscles was found better in noninfected school children than infected children with STH. These results indicate that none of the infected school children with STH had normal muscle strength values. ${ }^{[13]}$ Our study was similar with a study conducted in Yunan, China from 2011 to 2012 in children aged 9 to 12 years using the handgrip strength test, which reported that the value of muscle strength in children infected with STH was lower than non-infected children with STH. The study in Yunan also found that the relationship between STH infection and muscle strength still have limited evidence and requires further research. ${ }^{[14]}$ A cohort study conducted in southern Africa reported that muscle strength was significantly different in infected and non-infected school children with STH. ${ }^{[15]}$ Fatigue and nutrition factors probably could explain why in infected children with STH had lower hand muscle strength than non-infected school children with STH. Because one of the clinical symptoms that arise if a child is infected with STH is fatigue when doing physical activities, and a disturbance in nutrient intake, which can cause a deficiency of energy and protein. ${ }^{[16]}$

The value of muscle flexibility was lower in infected children with STH. Our study similar to a study conducted in Yunan in 2011 and 2012 that reported infected children with STH had lower muscle flexibility values than non-infected children with STH before receiving albendazole treatment. ${ }^{[17] .}$ 
Our study was the first to compare physical fitness in infected and non-infected children with STH in Indonesia. The method of measuring physical fitness in our study can be used as a reference to measure physical fitness in children.

\section{CONCLUSION}

Muscular strength and flexibility are weaker in infected school children compare to non-infected school children with STH. Based on the type of STH infection, children infected with T. trichiura were significantly different of muscular strength and flexibility than non-infected school children with T. trichiura. However, children infected with $A$. lumbricoides were different signs of muscular flexibility than non-infected school children with $A$. lumbricoides.

\section{REFERENCES}

1. Bethony J, Brooker S, Albonico M, Geiger SM, Loukas A, Diemert D, et al. Soiltransmitted helminth infections: ascariasis, trichuriasis, and hookworm. Lancet. 2006; 367:1521-32

2. World Health Organization. 2012 Soil-transmitted helminthiases, eliminating soil-transmitted helminthiases as a public health problem in children: progress report 2001-2010 and strategic plan 2011-2020. France: WHO Press; 2012

3. Hotez PJ, Brindley PJ, Bethony JM, King CH, Perace EJ. Helminth infections: the great neglected tropical diseases. J Clin Invest. 2008; 118: 131 1-21

4. Kementerian Kesehatan RI. Rencana aksi program pengendalian penyakit dan penyehatan lingkungan tahun 2015. Jakarta: Kementerian Kesehatan RI; 2015

5. Yap P, Du ZW, Chen R, Zhang LP, Wu WF, Wang J, et al. Soil transmitted helminth infections and physical in school-aged bulang children in southwest china : results from a cross-sectional survey. Parasits and Vectors. 2012; 5: 1-9

6. Bustinduy AL, Thomas CL, Fiutem JL, Parrage IM, Mungai PL, Muchiri EM, et al. Measuring fitness of kenyan children with polyparasitic. Plos. 2011: 5: 1-11

7. Yap P, Wu FW, Du ZW, Hattendorf J, Chen R, Jiang JY, et al. Effect of deworming on physical fitness of school-aged children in yunnan, china: a double-blind, randomized, placebo-controlled trial. Plos. 2014; 8: 1-12

8. Jiero S, Ali M, Pasaribu S, Pasaribu AP. 2015. Corelation between eosinophil count and soil-transmitted helminth infection in children. Asian Pas J Trop Dis 5(10):813-6

9. Pasaribu S.2004. Penentuan frekuensi optimal pengobatan massal askariasis dengan albendazole pada anak usia sekolah dasar di desa suka. Dissertation. University of Sumatera Utara, Medan, Indonesian, $195 \mathrm{p}$.

10. Cota LQ Morales-Figueora GG, Romero JE Valencia ME N-Garcia AH, Mendez RO, et al. Trichuriasis and low iron status in schoolchildren from Northwest Mexico. Eur J of Cli Nutr. 2010; 64: 1108-15

11. Dent EA, Kazura ZW. Trichuriasis (Trichuris trichiura). In: Kliegmen RM, Stanton BF, Schor NF, Geme JW, penyunting. Nelson textbook of Pediatrics. Edisi 20. Philadhelpia: Elsevier; 2016(1): 1736-7

12. Muller I, Yap P, Steimann P, Damons BP, Schinder C, Seelig H, et al. Intestinal parasites, growth and physical fitness of school children in poor neighbourhoods of port elizabeth, south africa: a cross sectional survey. Parasiter and Vectors. 2016; 9: 488-504

13. Rawat V, Rajesh SK, Nagarathna R. Physical fitness in adolescent competitive yoga pratitioners: a cross sectional cohort study. Indian J Health. 2014; 5: $1445-8$

14. Ruiz JR, Ortega FB, Guiterez A, Meusel D, Sjostrom M, Castillo MJ. Healthrelated fitness assessment in childhood and adolescence: a Europan approach based on the AVENA, EYHS and HELENA studies. J Public Health. 2006; 1: 1-9

15. Clayton PE, Gill MS. Normal growth and its endocrine control. In: Brook CGD, Hindmarsh PC, penyunting. Clinical pediatric endocrinology. Edisi ke-4. London: Blakwell science, 2003: 95-115.

16. Stephenson LS, Latham MC, Ottesen EA. Malnutrition and parasitic infections. Parasitology. 2000; 121: 23-38

17. Moncayo AL, Lovato R, Cooper PJ. Soil transmitted helminth infections and nutritional status in Ecuador: findings from a national survey and implications for control strategies. BMJ Open. 2018; 8: 1-10 